\title{
Mexican American Mobility: Early Life Processes and Adult Wealth Ownership
}

\author{
Lisa A. Keister, Duke University \\ Jody Agius Vallejo, University of Southern California \\ E. Paige Borelli, Duke University
}

$\mathrm{M}$

exican Americans are a large group whose mobility patterns can provide important insight into immigrant assimilation processes. It is well known that Mexicans have not attained economic parity with whites, but there is considerable debate about the degree to which Mexican immigrants and their Americanborn children experience mobility over their lives. We contribute to this literature by studying Mexican American wealth ownership, focusing on three interrelated processes. First, we examine childhood poverty and inheritances to establish financial starting points and to identify the degree to which resources from prior generations affect wealth ownership. Second, we study impediments to mobility in young adulthood to understand how childhood conditions create early adult obstacles to wellbeing. Third, we study midlife net worth and homeownership to better understand whether childhood and young adult impediments necessarily reduce adult wealth ownership. We find high levels of early life disadvantage among Mexican Americans, but these disadvantages are least pronounced in the second and third generations compared to the first generation. Consistent with prior research, we also find high levels of young adult impediments to mobility for Mexican Americans. However, we find that these early roadblocks do not necessarily translate into lower adult wealth: we show that Mexican Americans have less total wealth than whites but more than African Americans, even when early life impediments are controlled. Our results suggest that Mexican Americans are establishing a solid financial foundation that is likely to lead to long-term class stability.

The mobility prospects of Mexican Americans, a growing and important group in the United States, is one of the most intensely debated subjects in immigration studies. Two-thirds of American Latinos, or 32 million people, identify as Mexican (Motel and Patten 2012), and population growth among second- and

We acknowledge a grant from the National Science Foundation (SES-1322738) that supported this research. We are grateful for helpful comments and assistance from Richard Alba, David Eagle, Tomas Jimenez, Margarita Mooney, Victor Nee, Robert Reece, and Laura Tesch. Send correspondence to Lisa A. Keister, Duke University, 268 Sociology/Psychology Building, Durham, NC 27708; email:lkeister@soc.duke.edu. 
third-generation Mexican Americans is expected to double the US Latino population by 2040 (Passel and Cohn 2011). Because Mexicans tend to be disadvantaged even among immigrants (Agius Vallejo 2012; Bean and Stevens 2003; Feliciano 2005), evidence that Mexican Americans are upwardly mobile over the life course would suggest that an important class transformation is in progress. Mexican Americans as a group have not achieved economic parity with whites (Campbell and Kaufman 2006; Hao 2007; Taylor et al. 2011a), and scholars debate whether and to what extent Mexican Americans will incorporate into the host society or follow a pathway of downward mobility. Proponents of segmented assimilation theory argue that low parental socioeconomic status (SES), prevalence of unauthorized legal status, and a negative context of reception (i.e., Mexican Americans are seen as non-white and face discrimination) make downward mobility likely for Mexican immigrants. Consistent with this model, they find that second-generation Mexican American adolescents are likely to adopt elements of oppositional culture, do poorly in school, and otherwise show signs of downward assimilation (Haller, Portes, and Lynch 2011; Portes and Rumbaut 2001; Portes and Zhou 1993). Others counter that mobility prospects are less grim; they propose that there are many adaptation pathways available to immigrants, and research on cross-sectional and in-depth data provide evidence of upward educational and occupational mobility and identificational assimilation for Mexican Americans (Agius Vallejo 2012; Alba and Nee 2003; Perlmann 2005).

Wealth is an important indicator of class status and economic incorporation, and understanding the wealth mobility of Mexican immigrants and their American-born children has the potential to provide important insights into the immigrant mobility debate. Wealth (net worth) is often implied but rarely measured directly in studies of immigrant social and economic incorporation (Alba and Nee 2003; Portes, Haller, and Guarnizo 2002; Portes and Rumbaut 2006). Wealth ownership reflects most of the behaviors and processes that immigration scholars use to assess immigrant incorporation, including education, income, family structure, language ability, and legal status. Wealth is measured as total assets less total debts and is central to understanding assimilation because the accumulation of assets (e.g., housing, financial, business) can create short-term mobility and long-term class stability (Keister 2007; Spilerman 2000; Wolff and Zacharias 2009). Even a small amount of savings can improve financial security, mitigate the effects of economic shocks, and be transferred across generations to create long-term advantages. For immigrants, home and business ownership often hold particular significance and imply success, suggesting that wealth accumulation closely approximates immigrants' own conceptions of mobility and sense of becoming American (Agius Vallejo 2012; Alba and Nee 2003; Portes and Rumbaut 2006). Studying net worth for the same individuals over large portions of their lives is particularly useful, as it could improve understanding of mobility patterns that are obscured when lives are truncated or longitudinal data are unavailable. Moreover, wealth scholarship offers insights regarding the nature and determinants of mobility trajectories-including the potential for within-group heterogeneity and the centrality of education to mobility-that 
may be useful in understanding the nuances involved in Mexican American assimilation.

We contribute to the literature on immigrant adaptation by asking whether contemporary, adult Mexican Americans have experienced wealth mobility over their lives, and if so, in which direction. We start by synthesizing ideas from immigrant assimilation and wealth mobility research, which both refer to status in the larger social and economic structure, to conceive of mobility as a process that occurs across the life course and that is best understood when early life, adolescence, and adulthood are studied together. In doing so, we also contribute to clarifying and advancing the definition of mobility used in the immigrant assimilation literature. Using this definition and further drawing on both the immigration and mobility literatures, we then develop a series of hypotheses anticipating how Mexican Americans are likely to accumulate wealth over their lives, comparing them across the generations and to native-born whites and African Americans. We test these ideas using data from the National Longitudinal Survey of Youth, 1979 cohort (NLSY), which allows us to study wealth ownership from young adulthood through midlife for a large sample of first-, second-, and third-generation-plus Mexican Americans. We model three distinct processes that correspond to our definition of mobility. First, we model childhood financial well-being and inheritance receipt to establish baseline economic conditions and the degree to which inflows from previous generations affect adult wealth. Second, we follow immigration research by modeling impediments to mobility in young adulthood using a six-component index (Haller, Portes, and Lynch 2011). Third, we model adult wealth as homeownership and net worth at midlife. We include both measures of early life financial conditions and young adult impediments to mobility in models of adult homeownership and midlife wealth to identify whether these predict adult outcomes. We conclude by discussing the implications of our findings for immigrant mobility research.

\section{Mobility Debates: Implications for Mexican Americans}

Immigrant mobility debates involve three perspectives that use complementary theoretical ideas but make different empirical predictions. Segmented, mainline, and delayed assimilation perspectives each improved on the classical assimilation model, dominant in the early twentieth century, which assumed immigrants follow a linear path of integration into mainstream education and occupational structures (Gordon 1964). Segmented assimilation scholars conceive of downward mobility as movement toward a racialized underclass that is evident in stagnation in subordinate manual labor jobs or assimilation into deviant lifestyles. In contrast, upward mobility would be evident in full acculturation into the middle class (Portes and Rumbaut 2006; Portes and Zhou 1993; Zhou 1997). These researchers propose that rather than following a single path, the second generation follows one of two paths reflecting parents' SES, legal status, and the host-country context of reception. First-generation immigrants with high human capital who encounter a positive context of reception will have children (the second generation) who attain professional occupations and whose own children 
(the third generation) integrate completely into the mainstream. For those whose parents have low human or financial capital, enter the country illegally, or meet a negative context of reception because of racial/ethnic discrimination, upward mobility and integration into the middle class are unlikely (Haller, Portes, and Lynch 2011; Portes and Rumbaut 2001; Portes and Zhou 1993). Thus, a core assumption of this approach is that roadblocks in young adulthood are difficult to overcome and result in a pattern of downward mobility where the second generation displays socioeconomic characteristics that resemble those of poor African Americans.

From this perspective, Mexican immigrants are expected to be particularly disadvantaged and highly susceptible to downward mobility because many enter the United States illegally, with limited education (Feliciano 2006), and experience a negative social context in which their immigrant group is criminalized. Indeed, Mexican immigrants are seen as "the [emphasis in the original] textbook example of the theoretically anticipated effects of low immigrant human capital combined with a negative context of reception which cumulatively leads to downward mobility across the generations" (Portes and Rumbaut 2001, 279). Empirical tests of segmented assimilation compare young adults from various immigrant groups and find that Mexican American youth face many obstacles to upward mobility that will ensure that they follow a pathway of downward assimilation (Haller, Portes, and Lynch 2011).

Mainstream assimilation scholars agree that family background, legal status, and the context of reception interact to affect immigrant mobility. However, they conceive of mobility slightly differently. They agree that upward mobility implies movement toward the host-country mean or the mainstream, but they emphasize that the notion of a mainstream is multifaceted. As a result, their work focuses, in part, on providing conceptual and empirical precision to the mainstream concept (Alba 2008; Alba, Kasinitz, and Waters 2011). This perspective defines the mainstream as social spaces where the presence of the racial/ethnic majority is unproblematic (Alba 2008). Mainstream assimilation scholars do not dismiss the possibility of downward mobility or stagnation, but they conceive of class boundaries as more fluid than segmented assimilation theory and suggest that rather than following one of two pathways proposed by segmented assimilation theory, immigrants may follow multiple trajectories. A diversity of personal and family traits, experiences of racial discrimination, and contexts of reception combine to produce a large variety of outcomes, including for Mexican Americans (Agius Vallejo 2012; Alba, Jiménez, and Marrow 2013; Bean and Stevens 2003; Kasinitz et al. 2008). Mainstream assimilation researchers add that the idea that ethnicity impedes mobility is based on a black-white race relations model that assumes Mexican Americans are viewed and treated as more similar to African Americans than to non-Latino whites (Agius Vallejo 2012; Perlmann 2005). They argue that this model is not supported empirically and that class and ethnic boundaries, which were malleable enough in prior generations to allow white ethnic immigrants to integrate, may also foster upward mobility among Mexican Americans (Alba 2009; Smith 2005). Mainstream assimilation research documents many unique life-course trajectories for 
Mexican Americans (Agius Vallejo 2012; Alba, Jiménez, and Marrow 2013; Perlmann 2005), demonstrating that, although possible, downward assimilation is the exception rather than the norm (Waters et al. 2010). Similar to segmented assimilation research, most of this work draws conclusions from young adult outcomes or cross-sectional data, leaving questions about mobility over the life course unanswered.

A third perspective, delayed assimilation, concurs with mainstream assimilation scholars that downward mobility implies stagnation or movement away from the middle-class mean, while upward mobility is change that moves immigrants closer to the middle-class mean. However, these scholars underscore that the conditions of entry and legalization can create roadblocks to incorporation and result in within-group heterogeneity in the process of assimilation (Bean and Stevens 2003; Bean et al. 2011; Brown 2007). Mexican Americans, in particular, are likely to enter the United States as unskilled and possibly unauthorized sojourners (Chavez 1988) who initially intend to work temporarily and return home; over time, they may become settlers (Chavez 1988) as they shift their focus away from their country of origin and toward the host country (Bean et al. 2011; Brown 2007). This transition phase has the potential to delay assimilation; the second generation is likely to be generally successful in integrating into American society, but certain individuals and groups will experience lateral, downward, or delayed assimilation (i.e., it may take several generations to converge to the middle-class mean), depending on parents' traits and the context of reception (Bean and Stevens 2003; Kasinitz et al. 2008). These scholars make empirical comparisons with the native-born population and other immigrants, but they also emphasize that comparisons between parents and children are critical to understanding mobility in the second and later generations.

\section{Mobility and Life-Course Processes}

A rich tradition of research on socioeconomic mobility and life-course processes, including research on wealth ownership, can help clarify the meaning of mobility and contribute to an understanding of Mexican American attainment. Three ideas from this work are particularly relevant. First, this research emphasizes that mobility is best understood when starting points, intergenerational resource transfers, and changes over the life course are studied simultaneously. Shortterm dynamics and early adulthood are important, but it is only when important behaviors and processes (e.g., education, marriage) interact in complex ways over long periods that the true nature of a life trajectory emerges (Elder 1992; O'Rand and Krecker 1990). This assumption is foundational in mobility research and is supported empirically in work on education, occupation, income, and wealth mobility (Keister 2005; Warren and Hauser 1997). Research on immigrant assimilation has a traditional sociological mobility model at its core and thus makes similar assumptions: all three assimilation perspectives imply or explicitly argue that childhood, young adult, and adult processes are important components of mobility, but previous research has not studied these stages simultaneously. 
Second, evidence from mobility and life-course research suggests that upward mobility is possible if demographic and social conditions are conducive. Consistent with immigrant assimilation research proposing that multiple paths of incorporation are possible, mobility research shows that there is likely to be considerable within-group heterogeneity in the trajectories that individuals follow, reflecting the many behaviors and processes that interact to create adult attainment. Mobility scholars have studied detailed, longitudinal data on individual life courses for multiple cohorts, and they find that many demographic, cognitive, and social processes combine to create life trajectories (Corcoran 1995; Keister 2011; Solon 1992). Moreover, variations in the salience and timeordering of these processes can produce many pathways even within seemingly homogeneous groups and upward mobility for even the most disadvantaged (Keister 2005, 2007; Kurz and Muller 1987). This does not imply that all members of disadvantaged groups will be upwardly mobile, but it does show that a variety of life outcomes are possible from similar starting points.

Finally, mobility research shows that education can overshadow most other predictors of life outcomes that might otherwise prevent mobility (Hauser and Mossel 1985; Warren and Hauser 1997). Education was a primary component of early mobility models (Blau and Duncan 1967), and contemporary research finds that education can outweigh early life roadblocks (e.g., early fertility and delinquency) (Harris 1997; Haynie, South, and Bose 2006). Although research on immigrant attainment emphasizes the centrality of education, few empirical studies have compared the salience of education and other processes in creating mobility. In addition, there is no agreement within the assimilation literature as to whether educational attainment is an outcome or conduit of upward mobility.

\section{Mexican American Wealth Ownership}

To better understand Mexican American wealth ownership, we draw on ideas from both the assimilation literature and the literatures on mobility and lifecourse processes. We follow the assimilation literature to define downward mobility as stagnation or movement away from the middle-class mean and upward mobility as movement toward the middle-class mean. However, we integrate ideas from the mobility and life-course literatures to define mobility as involving three distinct life-course stages and processes: (1) early life states (e.g., financial status and transfers across generations); (2) adolescent impediments to mobility; and (3) adult processes, including homeownership and midlife wealth attainment. We integrate ideas from both assimilation and mobility/life-course research in identifying our reference groups. We compare Mexican Americans to non-Latino whites and African Americans, and we detail differences among first-, second-, and third-generation-plus individuals from the same cohort to show within-group differences in wealth trajectories. By studying Mexican American starting points, we implicitly compare them to their parents, as a child's poverty status and receipt of intergenerational transfers reflect parental SES. In using these comparison groups, we follow the wealth literature, in which the status of whites and African Americans is well established (Oliver and Shapiro 1995); 
and the assimilation literature, in which comparisons to native-born groups are considered essential for understanding assimilation trajectories (Alba, Kasinitz, and Waters 2011; Alba and Nee 2003; Waters and Jiménez 2005).

\section{Starting Point: Childhood Poverty and Inheritances}

Childhood poverty and intergenerational resource transfers are important indicators of a person's starting point in life and the degree to which prior generations' well-being affects a person's wealth. Because Mexican migration is largely a low-wage labor migration (Agius Vallejo 2012; Bean and Stevens 2003), most Mexican immigrants have low human capital and working-class occupational experience, forcing them to accept low-wage jobs in the United States (Feliciano 2005; Massey, Durand, and Malone 2003; Zhou et al. 2008). Approximately one-half of new Mexican immigrants are unauthorized (Taylor et al. 2011b), exacerbating the challenges of finding stable employment. A high propensity to send remittances and help relatives in the United States, particularly for the first generation (Lopez, Livingston, and Koshar 2009), increases financial burdens. These migration-related factors all contribute to higher poverty rates for Mexican Americans than native whites (Motel and Patten 2012; Telles and Ortiz 2008).

However, despite their disadvantage relative to whites, demographic changes across the generations of Mexican Americans suggest that an important class transformation is underway. Significant changes are occurring across the generations for Mexican Americans, including changes in educational attainment, legal status, marriage, family size, geography of residence, and other traits that predict SES. As such, generation since migration measures vulnerability to racism at one end of the spectrum and similarity to the mainstream at the other (Alba, Jiménez, and Marrow 2013). Education is one of the strongest predictors of wealth, and evidence suggests that the second and subsequent generations surpass their parents on educational attainment even with continued issues related to legal status (Bean and Stevens 2003; Park and Myers 2010; Smith 2003). Despite continuing constraints on educational and occupational advancement (Haller, Portes, and Lynch 2011; Tienda 2010), record numbers of Mexican Americans are entering college and completing college degrees (US Census 2012). Even modest gains in education and occupation relative to prior generations can have significant positive effects and cumulative advantages on earnings, career mobility, use of formal financial organizations, and nonwage benefits such as retirement plans. Marriage and family behaviors are also important correlates of SES (Zagorsky 2005), and these are also changing for Mexican Americans: marriage rates and stability are high across the generations, age at first marriage and age at first birth have increased, and family size has simultaneously declined (Bean and Stevens 2003; Lloyd 2006; Parrado 2011). In addition, as social connections in the United States become stronger, the importance of remitting declines (Ortmeyer and Quinn 2012). These patterns suggest that there will be differences in financial well-being when we compare first-, second-, and third-generation-plus individuals in the same cohort. That is: 
H1A. Mexican Americans have not reached economic parity with whites, but poverty rates are likely to be lower and inheritance rates are likely to be higher for Mexican Americans in this cohort when we compare the first, second, and third generations, respectively.

Comparison to whites, who comprise the majority group in America in terms of economic, social, and political power, is important, but it is perhaps more useful to compare Mexican American mobility to that of African Americans, who experience racialization and have consistently low median wealth levels (Taylor et al. 2011a). Both first-generation Mexican Americans and African Americans face acute disadvantage on all SES measures, but the added challenges of financial commitments to family in the home country, legal status, and English abilities are likely to intensify the disadvantage encountered by recent Mexican immigrants. This suggests that first-generation Mexican Americans will have higher poverty rates and lower intergenerational transfer rates than African Americans. However, building on our expectations that poverty will decline and inheritances will increase with each generation since migration, we also expect second- and later-generation Mexican Americans to have some advantages over African Americans. Although African Americans have experienced increased educational attainment similar to Mexican Americans (US Census 2012), a historical legacy of economic discrimination and contemporary racialization result in smaller economic returns to wealth-building processes (e.g., education, marriage, homeownership) for African Americans than for Mexican Americans (Conley 1999; Shapiro 2004). Yet, these racialization processes do not operate identically for Mexican Americans, some of whom identify themselves and are viewed as closer to white Americans (Lee and Bean 2010). This suggests:

H1B. First-generation Mexican Americans are more likely than African Americans to be raised in poverty and less likely to receive inheritances; the second and later generations are less likely than African Americans to be raised in poverty and more likely to receive transfers.

\section{Young Adulthood: Impediments to Mobility}

Young adulthood is another important life stage that may affect social mobility and long-term well-being. Immigration scholars agree that young adult processes are important, but they disagree about what the empirical evidence implies for second-generation mobility. Mainstream and delayed assimilation scholars show that educational and occupational attainment are higher when secondgeneration young adults, including Mexican Americans, are compared with their parents (Agius Vallejo 2012; Alba, Jiménez, and Marrow 2013; Kasinitz et al. 2008). They conclude that this demonstrates movement of Mexican Americans into the middle class. In contrast, segmented assimilation researchers argue that mobility is better measured using longitudinal data on members of the second generation as they move from childhood, when they assume their parents' status, to young adulthood, when they have achieved their own status. These scholars also propose that there are many issues confronting the second generation that 
contribute to downward assimilation by young adulthood. In a recent example, segmented assimilation scholars used an index of impediments to mobility that includes dropping out of school, unemployment, early fertility, arrest, and incarceration as indicators of downward assimilation to study the second generation in their mid-20 s (Haller, Portes, and Lynch 2011; Portes, Fernandez-Kelly, and Hall 2005). They found that Mexican Americans score relatively high on this index, and they argued that this is evidence that these young adults are on a downwardly mobile path, leaving Mexican Americans mired in poverty over the generations (Haller, Portes, and Lynch 2011; Portes and Fernandez-Kelly 2008).

Segmented assimilation scholars are likely correct that second-generation Mexican American young adults encounter disproportionately high impediments to mobility. Indeed, this is consistent with our argument that Mexican Americans face high rates of childhood poverty: people who were raised in poverty are highly likely to drop out of school, become unemployed, have children early in life, and become involved in countercultural activities that lead to arrest and incarceration. In their empirical work, segmented assimilation theorists have compared various immigrant groups, and Mexican Americans score relatively high on composite measures of impediments to mobility relative to other immigrants (Haller, Portes, and Lynch 2011). It follows that Mexican Americans will face considerable obstacles to mobility relative to whites, and we expect that impediments to mobility in young adulthood will mirror patterns of childhood poverty.

H2. Mexican Americans will face more impediments to mobility in young adulthood than non-Latino whites and a comparable number of impediments to African Americans.

\section{Adult Processes: Homeownership and Midlife Wealth}

Although young adulthood is an important life stage, mobility is not complete by the mid-20 s, and experiencing impediments to mobility in early life does not guarantee downward mobility or even make it the most common resulting adult trajectory (Alba, Kasinitz, and Waters 2011; Waters et al. 2010). Segmented assimilation scholars examine individuals as adolescents and young adults; they do not study the same people in early and later life. However, mobility research has shown that understanding life paths requires studying early and later life well-being together to fully understand cumulative advantage or disadvantage. The mobility and immigrant attainment literatures suggest two likely hypotheses concerning Mexican American later life outcomes. Upward mobility is possible for Mexican Americans, despite early impediments, because of rising education levels, changes in related financial behavior, and the presence of important social relations. Education is critical to achieving upward mobility in adulthood. Segmented assimilation research includes dropping out of high school in its downward assimilation index, but despite early dropouts, overall education levels are rising for Mexican Americans (Agius Vallejo 2012; Bean and Stevens 2003; Perlmann 2005). Mobility research also shows that ultimate educational 
attainment can overshadow the effects of other impediments because it affects family behaviors, saving rates, and the mix of assets people own over time (Keister 2004). Similar demographic changes benefit Mexican Americans: rising education levels have facilitated greater saving rates, homeownership, and financial asset and business ownership (Campbell and Kaufman 2006; Clark 2001; Hao 2007). Added to these processes, Mexican Americans may have family (Agius Vallejo 2012; Alba and Nee 2003; Clark, Glick, and Bures 2009) and community (Agius Vallejo 2009; Kasinitz et al. 2008) ties that can buffer against downward mobility by providing work and financial resources.

Midlife wealth ownership is a critical indicator of status and mobility because most people have established an SES position by this life stage, and SES tends to be quite stable in subsequent years. Therefore, midlife SES can be used to indicate mobility attained over the life course and preparation for impending retirement. At this life stage, total wealth or net worth continues to be an important indicator of well-being, but the components of net worth, particularly homeownership, are also significant. Because the primary residence is a significant component of household wealth for many Americans (Bricker et al. 2012), it has a history of use across the social sciences as a proxy for total wealth (Charles and Hurst 2002; Henretta 1984; Spilerman and Wolff 2012). Moreover, homeownership is considered by scholars in many fields to be an important component of being (or becoming) part of the American mainstream (Hao 2007; Myers 2008; Spilerman and Wolff 2012). Although homeownership rates are low for recent Mexican immigrants, their participation in the housing market increases precipitously as their US tenure increases and by generation; however, first-generation Mexican Americans do not achieve homeownership rates on par with those of US-born natives (Alba and Logan 1992; Myers and Lee 1998). Thus, we anticipate that:

H3A. At midlife, Mexican Americans are less likely than whites but more likely than African Americans to own their homes, and young adulthood impediments to mobility reduce the likelihood of homeownership.

H3B. At midlife, Mexican Americans have less total wealth than whites but more than African Americans, and young adulthood impediments to mobility decrease midlife wealth.

\section{Data and Research Design}

To test these ideas, we use data from the National Longitudinal Survey of Youth, 1979 cohort (NLSY). The Bureau of Labor Statistics administered the first NLSY to a nationally representative sample of 12,686 young adults (ages 14 to 22) in 1979. They conducted follow-up surveys annually until 1994 and biennially until 2008, when respondents were ages 43 to 51 . These data are ideal for this study because they contain a sizable Mexican American sample and detailed, longitudinal information about family background, individual and household processes, transitions to adulthood, and adult outcomes, including wealth. Because this is a cohort data set, it allows us to study relative mobility 
while largely controlling for absolute mobility. Other nationally representative data sets include longitudinal wealth data, but Mexican American sample sizes are much smaller in other data sets and longitudinal coverage is less consistent. The NLSY wealth modules (started in 1985) include reliable and comprehensive information on ownership and value of assets and debts. The NLSY also contains detailed data on ethnicity, country of origin, and nativity that allow us to identify and study first-, second-, and third-generation Mexican Americans in the same cohort. Although our reference group is non-Latino white respondents, we do not separate whites by generation because prior research and our estimates of the NLSY data show that wealth differs little across generations for whites (Hao 2007). We include Puerto Rican, Cuban, and non-Latino black respondents in our analyses for comparison. Our sample contains 11,718 respondents, including 1,112 Mexican Americans spread across three generations (see table 1). Sensitivity tests confirm that sample sizes for all groups that we include are large enough to provide robust estimates.

We use self-reports of ethnicity, country of origin, and parents' traits (1979 interview) to identify Mexican Americans by generation. First generation are immigrants, second generation are those born in the United States to immigrant parents, and third generation plus are those born to the second-generation or later immigrants who continue to identify as Mexican. The NLSY also includes interviewer reports of ethnicity in 1979 and additional respondent reports in 2002; these are highly consistent with the respondent reports we use, and we find no evidence of ethnic attrition (Alba, Jiménez, and Marrow 2013; Emeka and Agius Vallejo 2011). This sample is representative of Mexican American youths living in the United States in 1979 and of midlife Mexican Americans today on many important demographic traits; thus, this sample is not representative of a current cross-section of Mexican Americans (Keister 2005). The sample is relevant to understanding immigrant assimilation because it is longitudinal for individuals; this is critical to resolving issues about immigrant mobility because we connect starting points, young adulthood, and midlife to study large portions of the life course simultaneously. Moreover, analyzing longitudinal changes within a single cohort allows us to control for temporal fluctuations in opportunities that are external to groups and that are implicit in birth cohort analysis (Waters and Jiménez 2005). Although the longitudinal analysis is a significant contribution to the literature, our data are cross-sectional by generation. Thus, the data do not allow us to analyze intergenerational mobility between the first, second, and third generation. However, there is utility in describing differences between generations in this sample because it illustrates important within-group variations in starting points in a single cohort that are critical to wealth mobility over the life course. There was some sample attrition: nearly 10 percent of the full sample was not contacted consistently. Sample sizes vary across survey years, although respondents who are missing in one year may reenter the sample in later years. Attrition rates for Mexican Americans are consistent with those of other groups and are relatively even across the generational groups; sensitivity analyses suggest that there is little effect of attrition on our results. 
Table 1. Mexican American Wealth: Descriptive Statistics

\begin{tabular}{lccccc}
\hline & Sample $n(\%)$ & $\begin{array}{c}\text { Childhood } \\
\text { poverty }\end{array}$ & $\begin{array}{c}\text { Ever } \\
\text { inherit }\end{array}$ & $\begin{array}{c}\text { Impediments } \\
\text { to mobility } \\
\text { (no.) }\end{array}$ & $\begin{array}{c}\text { Net worth, } \\
\text { 2008 } \\
(000 \mathrm{~s}, \mathbf{S})\end{array}$ \\
\hline Mexican American & $1,112(9.5)$ & .33 & .04 & 1.76 & 127.08 \\
\hline First generation & $315(2.7)$ & .38 & .02 & 1.83 & 105.13 \\
\hline Second generation & $341(2.9)$ & .32 & .03 & 1.60 & 135.20 \\
\hline Third generation plus & $456(3.9)$ & .32 & .04 & 1.61 & 142.24 \\
\hline African American & $3,147(26.8)$ & .33 & .03 & 1.59 & 43.1 \\
\hline Puerto Rican & $308(2.6)$ & .34 & .03 & 1.71 & 107.80 \\
\hline Cuban & $112(1.0)$ & .13 & .20 & .97 & 197.33 \\
\hline White & $7,058(60.2)$ & .17 & .19 & 1.28 & 330.45 \\
\hline All & $11,718(100)$ & .21 & .09 & 1.42 & 188.00 \\
\hline
\end{tabular}

\begin{tabular}{lrllr}
\hline Family background & \multicolumn{3}{l}{ Individual and family traits } \\
\hline Father graduated from college & .10 & Age (years) & 49.53 \\
\hline Mother graduated from college & .07 & Male & .49 \\
\hline Father worked full-time & .77 & High school graduate & .36 \\
\hline Mother worked full-time & .40 & Some college & .18 \\
\hline Father had professional occupation & .10 & College graduate & .12 \\
\hline Mother had professional & .03 & Advanced degree & .08 \\
occupation & & & .12 \\
\hline Family income in 1978 (000 s) & $\$ 47.88$ & Labor occupation & $\$ 61.21$ \\
\hline Stepparent family & .08 & Annual family income $(000$ s) & $\$ 67.78$ \\
\hline Single-parent family & .13 & Welfare income (monthly) & $\$ 465$ \\
\hline Siblings (number) & 2.95 & Two-earner household & 21 \\
\hline Married & .51 & Age at first birth (years) & 1.7 \\
\hline Separated & .04 & Children (number born) & \\
\hline Divorced & .12 & & \\
\hline Widowed & .004 & & \\
\hline
\end{tabular}

Note: Values are proportions unless otherwise specified. Income and wealth values are medians adjusted to 2010 dollars; other values are means. Adult traits are measured in $\mathbf{2 0 1 0}$ for this table, but we use data from 1979 to 2008 in our analyses. Net worth is higher for this sample than for the US population because this is a cohort sample with a mean age of 49. To conserve space, we do not include all variables in the table. Some proportions do not sum to 1 because of rounding.

We have basic information on respondent legal status and visa type from the 1979 interview, but 99 percent of our respondents reported being legal residents or US citizens. Unfortunately, the NLSY did not probe further regarding legal status and related issues, and they did not request information on parents' 
legal status. Nonetheless, we explored whether wealth and other traits varied by legal status but found no substantive difference. Although we cannot clarify legal status, we expect that immigrant parents and respondents who were unauthorized in the 1970s and early 1980s eventually obtained legal status through various channels, such as IRCA (Immigration Reform and Control Act of 1986) amnesty.

\section{Dependent Variables}

We use several dependent variables to test our hypotheses. First, we model childhood poverty and inheritances to identify the degree to which prior generations facilitated wealth accumulation. Childhood poverty is a dichotomous measure indicating whether the respondent's childhood household income (age 14) was below the national poverty line. We use a dichotomous indicator to capture the disadvantages associated with being below this threshold; results do not change when we use continuous measures. Ever inherit is a dichotomous measure indicating whether the respondent has ever received direct wealth transfers from prior generations as cash gifts, trust accounts, or other transfers (including inheritance and inter vivos transfers). Because most people who inherit receive small amounts, modeling the dollar amount of inheritances is less meaningful than measuring receipt of transfers.

Second, we measure impediments to mobility using an index that is constructed identically to the downward assimilation index used by segmented assimilation theorists: a count variable indicating negative outcomes in young adulthood (Haller, Portes, and Lynch 2011). To construct this index, we aggregated six indicators into a single summary measure constructed when our respondents were 24 years old, the same age as the respondents used by Haller and his coauthors. The indicators are (1) dropped out of high school; (2) annual income below the poverty line; (3) unemployed and not in school; (4) had at least one child; (5) had at least one arrest (but not incarcerated); and (6) had at least one incident of incarceration. Other education, income, and family processes occurring after age 24 are reflected in our other control variables (see below).

Third, we model midlife wealth using homeownership and total net worth in 2008 (i.e., in midlife). To measure midlife homeownership, we modeled a dichotomous variable indicating whether the respondent owned their home in 2008. To model total midlife net worth, we constructed an annual net worth measure (total assets less total debts) from detailed respondent reports of household asset and debt ownership (yes/no) and value (total current market value) adjusted to 2008 dollars with the consumer price index. Data collected in 2010 are highly irregular, due to the financial crises, so we limit our analyses to wealth data collected between 1985 and 2008. Assets include stocks, bonds, cash accounts, trusts, retirement accounts, certificates of deposit, primary residence, other real estate, vehicles, and other possessions. Debts include mortgages on the primary residence and other real estate, consumer loans, student loans, vehicle loans, and other debt. Using alternative definitions of wealth-gross assets (i.e., the sum of all assets not reduced by liabilities), total financial assets, total nonfinancial 
assets, or total liabilities-produced comparable results. Removing outliers also did not change the results substantively.

\section{Control Variables}

We control for many behaviors and processes that affect wealth. In models of childhood family poverty and inheritances, we control parents' SES with measures of parents' education, whether the respondent's parents worked full-time in 1978, and parents' occupations. We also control for family size and resource dilution with measures of family structure at age 14, number of siblings, and a dichotomous variable indicating whether extended family members lived in the household. We include an indicator that the respondent moved more than three times during childhood to indicate geographic instability, which reduces financial well-being. We control for region of residence and urban residence to capture Latino geographic concentration: first-generation Mexican Americans are concentrated in the West, but this is less true for the second and third generations, who were more likely than the first generation to move to the Southeast. Finally, we control for basic demographics: age, age squared, and gender.

In impediments to mobility models, we include fewer controls to avoid controlling components of the dependent variable; we control parental educational attainment, net family income in 1978 (logged), and childhood family characteristics. We also include measures of age, gender, region of residence, and urban residence. In models of midlife homeownership and wealth, we continue to control for family background and basic demographics. We also control for early life experiences with indicators of childhood poverty, inheritance receipt, and young adult impediments. We control for respondents' education with dichotomous variables indicating highest level completed; we omit those who did not complete high school. We control for household income, a continuous variable measured annually in thousands of dollars. We also control for family processes with indicators of marital status, number of children, and number of children squared to capture the curvilinear relationship between family size and wealth. Including the dichotomous and continuous indicators forces the continuous indicators to drop out of the equation when the respondent has no children. In models of midlife wealth, we include an indicator of whether the respondent owned a home in 1998.

\section{Model Details}

We model well-being at three important life stages consistent with our definition of mobility: (1) early life states; (2) adolescent impediments to mobility; and (3) midlife wealth. We use logistic regression to model childhood poverty and inheritances (table 2) and homeownership (table 4), negative binomial regression to model the count of impediments to mobility (table 3 ), and generalized least squares (GLS) regression to model total net worth in 2008 (table 5). The negative binomial models address overdispersion in the data, and the GLS models (a maximum likelihood estimator) address heteroskedasticity and correlation among observations. 


\section{Findings: Poverty and Inheritance}

Descriptive statistics in table 1 provide preliminary support for our hypotheses. Consistent with historical evidence, just more than 20 percent of the sample lived in poverty in 1979, and fewer than 10 percent ever inherited any financial resources from a prior generation. Whites were considerably less likely than others to grow up in poverty and more likely to inherit; African Americans were likely to live in poverty as children and unlikely to inherit. Childhood poverty rates for all Mexican Americans are similar to those of African Americans; poverty rates are smaller by generation when we compare first-, second-, and thirdgeneration individuals in the same cohort. Likewise, the likelihood of inheriting is low for Mexican Americans, but it increases slightly by generation when we compare first-, second-, and third-generation individuals in the same cohort.

Multivariate models provide additional support for our first hypothesis that Mexican Americans are more likely to experience childhood poverty and are less likely to inherit than whites. Table 2 includes estimates from logistic regression models predicting whether the respondent's childhood family income was below the poverty line and receipt of financial transfers from prior generations. Consistent with H1A, Mexican Americans are significantly more likely than whites to have been raised in poverty and significantly less likely to inherit. These findings are consistent with other research showing that poverty rates are high for Mexican Americans compared with non-Latino whites (Leach 2013; Motel and Patten 2012; Telles and Ortiz 2008) and reflect the reality that Mexican immigrants tend to have low education and working-class occupational experiences that translate into low-wage jobs in the United States (Feliciano 2005; Massey, Durand, and Malone 2003; Zhou et al. 2008). Furthermore, our finding that Mexican Americans are more likely than non-Latino whites to experience childhood poverty remains robust when we control for family characteristics, but model 3 differentiates first-, second-, and third-generation immigrants in this cohort and shows that the likelihood of being raised in poverty is smaller by generation since migration when comparing first-, second-, and third-generation individuals, respectively. Model 6 shows that the likelihood of receiving an intergenerational transfer is greater for generations two and three than for generation one. These findings underscore recent work showing considerable within-group differences for Mexican Americans, suggesting that downward mobility is not inevitable (Alba, Jiménez, and Marrow 2013).

These analyses also show that Mexican Americans overall are less likely than African Americans to be raised in poverty; however, model 3 shows that first-generation Mexican Americans are more likely than African Americans to be raised in poverty, but second- and later-generation Mexican Americans in this cohort are less likely than African Americans to be raised in poverty. In other words, the second and later generations in this cohort start their lives in better financial conditions than African Americans. A similar pattern emerges in models of inheritances. Model 4 indicates that Mexican Americans are less likely overall to receive inheritances, and this pattern remains robust when we add family background characteristics in model 5 . However, model 
Table 2. Childhood Poverty \& Intergenerational Transfers: Logistic Regression

\begin{tabular}{|c|c|c|c|c|c|c|}
\hline & \multicolumn{3}{|c|}{ Childhood poverty } & \multicolumn{3}{|c|}{ Ever inherit } \\
\hline & 1 & 2 & 3 & 4 & 5 & 6 \\
\hline $\begin{array}{l}\text { Mexican } \\
\text { American }\end{array}$ & $\begin{array}{l}0.79 * * * \\
(0.08)\end{array}$ & $\begin{array}{l}0.46 * * * \\
(0.09)\end{array}$ & - & $\begin{array}{l}-1.18 * * * \\
(0.08)\end{array}$ & $\begin{array}{l}-0.82 * * * \\
(0.09)\end{array}$ & - \\
\hline $\begin{array}{l}\text { First } \\
\text { generation }\end{array}$ & - & - & $\begin{array}{l}0.72 * * * \\
(0.14)\end{array}$ & - & - & $\begin{array}{l}-1.07 * * * \\
(0.17)\end{array}$ \\
\hline $\begin{array}{l}\text { Second } \\
\text { generation }\end{array}$ & - & - & $\begin{array}{l}0.39 * * \\
(0.14)\end{array}$ & - & - & $\begin{array}{l}-0.61 * * * \\
(0.15)\end{array}$ \\
\hline $\begin{array}{l}\text { Third } \\
\text { generation plus }\end{array}$ & - & - & $\begin{array}{c}0.13 \\
(0.13)\end{array}$ & - & - & $\begin{array}{l}-0.60 * * * \\
(0.12)\end{array}$ \\
\hline $\begin{array}{l}\text { African } \\
\text { American }\end{array}$ & $\begin{array}{l}0.91 * * * \\
(0.05)\end{array}$ & $\begin{array}{l}0.51 * * * \\
(0.06)\end{array}$ & $\begin{array}{l}0.51 * * * \\
(0.06)\end{array}$ & $\begin{array}{l}-0.88 * * * \\
(0.08)\end{array}$ & $\begin{array}{l}-0.72 * * * \\
(0.06)\end{array}$ & $\begin{array}{l}-0.72 * * * \\
(0.06)\end{array}$ \\
\hline Puerto Rican & $\begin{array}{l}1.26 * * * \\
(0.13)\end{array}$ & $\begin{array}{l}0.45 * * \\
(0.15)\end{array}$ & $\begin{array}{l}0.46 * * \\
(0.15)\end{array}$ & $\begin{array}{l}-1.39 * * * \\
(0.16)\end{array}$ & $\begin{array}{l}-0.10 * * * \\
(0.17)\end{array}$ & $\begin{array}{l}-1.00 * * * \\
(0.17)\end{array}$ \\
\hline Cuban & $\begin{array}{l}-0.55 \\
(0.31)\end{array}$ & $\begin{array}{l}-0.63 \\
(0.33)\end{array}$ & $\begin{array}{l}-0.63 * \\
(0.33)\end{array}$ & $\begin{array}{c}0.06 \\
(0.22)\end{array}$ & $\begin{array}{c}0.14 \\
(0.23)\end{array}$ & $\begin{array}{c}0.14 \\
(0.23)\end{array}$ \\
\hline \multicolumn{7}{|l|}{ Father's education } \\
\hline High school & - & $\begin{array}{l}-0.40 * * * \\
(0.06)\end{array}$ & $\begin{array}{l}-0.39 * * * \\
(0.06)\end{array}$ & - & $\begin{array}{l}0.30 * * * \\
(0.06)\end{array}$ & $\begin{array}{l}0.30 * * * \\
(0.06)\end{array}$ \\
\hline Some college & - & $\begin{array}{l}-0.55 * * * \\
(0.12)\end{array}$ & $\begin{array}{l}-0.54 * * * \\
(0.12)\end{array}$ & - & $\begin{array}{l}0.33 * * \\
(0.09)\end{array}$ & $\begin{array}{l}0.33 * * \\
(0.09)\end{array}$ \\
\hline College degree & - & $\begin{array}{l}-0.46 * * \\
(0.14)\end{array}$ & $\begin{array}{l}-0.45 * * \\
(0.14)\end{array}$ & - & $\begin{array}{l}0.68 * * * \\
(0.10)\end{array}$ & $\begin{array}{l}0.68 * * * \\
(0.10)\end{array}$ \\
\hline $\begin{array}{l}\text { Advanced } \\
\text { degree }\end{array}$ & - & $\begin{array}{l}-0.38 * \\
(0.18)\end{array}$ & $\begin{array}{l}-0.38 * \\
(0.18)\end{array}$ & - & $\begin{array}{l}0.82 * * * \\
(0.13)\end{array}$ & $\begin{array}{l}0.83 * * * \\
(0.13)\end{array}$ \\
\hline \multicolumn{7}{|c|}{ Mother's education } \\
\hline High school & - & $\begin{array}{l}-0.54 * * * \\
(0.06)\end{array}$ & $\begin{array}{l}-0.53 * * * \\
(0.06)\end{array}$ & - & $\begin{array}{l}0.41 * * * \\
(0.06)\end{array}$ & $\begin{array}{l}0.41 * * * \\
(0.06)\end{array}$ \\
\hline Some college & - & $\begin{array}{l}-0.44 * * * \\
(0.11)\end{array}$ & $\begin{array}{l}-0.44 * * * \\
(0.11)\end{array}$ & - & $\begin{array}{l}0.67 * * * \\
(0.09)\end{array}$ & $\begin{array}{l}0.67 * * * \\
(0.09)\end{array}$ \\
\hline College degree & - & $\begin{array}{l}-0.73 * * * \\
(0.18)\end{array}$ & $\begin{array}{l}-0.73 * * * \\
(0.18)\end{array}$ & - & $\begin{array}{l}0.86 * * * \\
(0.13)\end{array}$ & $\begin{array}{l}0.87 * * * \\
(0.13)\end{array}$ \\
\hline $\begin{array}{l}\text { Advanced } \\
\text { degree }\end{array}$ & - & $\begin{array}{l}-0.44 \\
(0.26)\end{array}$ & $\begin{array}{l}-0.44 \\
(0.26)\end{array}$ & - & $\begin{array}{l}0.83 * * * \\
(0.19)\end{array}$ & $\begin{array}{l}0.83 * * * \\
(0.19)\end{array}$ \\
\hline $\begin{array}{l}\text { Father worked } \\
\text { full-time }\end{array}$ & - & $\begin{array}{l}-0.80 * * * \\
(0.05)\end{array}$ & $\begin{array}{l}-0.80 * * * \\
(0.05)\end{array}$ & - & $\begin{array}{c}0.07 \\
(0.06)\end{array}$ & $\begin{array}{c}0.07 \\
(0.06)\end{array}$ \\
\hline
\end{tabular}




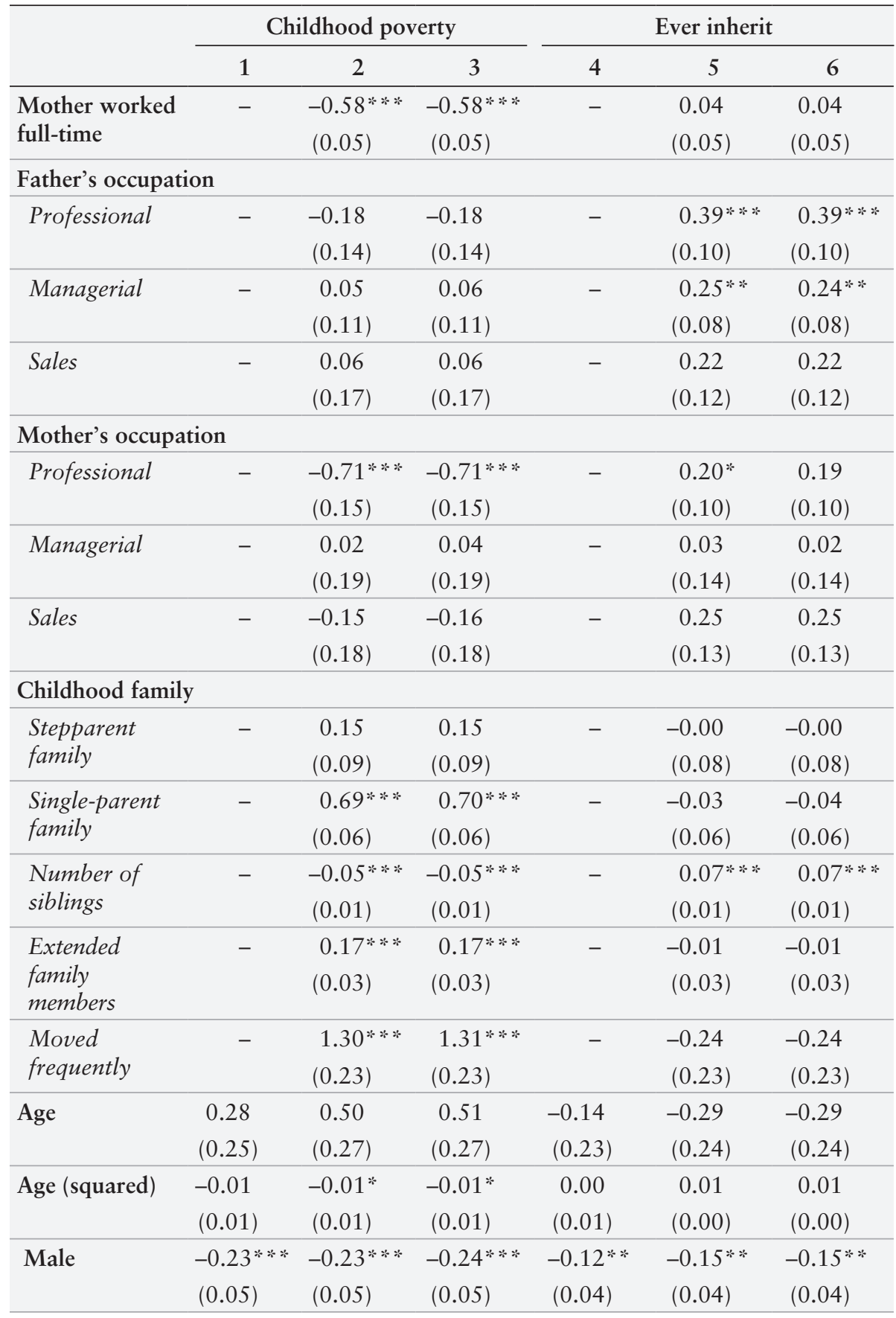


Table 2. continued

\begin{tabular}{|c|c|c|c|c|c|c|}
\hline & \multicolumn{3}{|c|}{ Childhood poverty } & \multicolumn{3}{|c|}{ Ever inherit } \\
\hline & 1 & 2 & 3 & 4 & 5 & 6 \\
\hline \multicolumn{7}{|c|}{ Region of residence } \\
\hline \multirow[t]{2}{*}{ North Central } & $-0.18 *$ & -0.15 & -0.14 & $-0.20 * *$ & $-0.22 * *$ & $-0.23 * *$ \\
\hline & $(0.08)$ & $(0.08)$ & $(0.08)$ & $(0.07)$ & $(0.07)$ & $(0.07)$ \\
\hline \multirow[t]{2}{*}{ South } & $0.17 * *$ & $0.21 * *$ & $0.22 * *$ & $-0.23 * * *$ & $-0.18 * *$ & $-0.19 * *$ \\
\hline & $(0.07)$ & $(0.07)$ & $(0.07)$ & $(0.06)$ & $(0.06)$ & $(0.06)$ \\
\hline \multirow[t]{2}{*}{ West } & -0.08 & 0.00 & -0.02 & 0.00 & -0.05 & -0.05 \\
\hline & $(0.08)$ & $(0.09)$ & $(0.09)$ & $(0.07)$ & $(0.08)$ & $(0.08)$ \\
\hline \multirow[t]{2}{*}{ Urban } & $-0.26 * * *$ & $-0.14 * *$ & $-0.14 * *$ & $0.31 * * *$ & $0.17 * *$ & $0.17 * *$ \\
\hline & $(0.05)$ & $(0.06)$ & $(0.06)$ & $(0.05)$ & $(0.05)$ & $(0.05)$ \\
\hline
\end{tabular}

Note: Standard errors are in parentheses. Childhood poverty indicates that childhood household income was below the poverty line. Inheritance indicates that the respondent ever received an intergenerational transfer from an older generation.

*** $p<0.001{ }^{* *} p<0.01 * p<0.05$

6 shows that this pattern is accounted for mostly by first-generation Mexican Americans. First-generation Mexican Americans in this cohort are less likely than African Americans to receive inheritances, but second- and later-generation individuals in this cohort are more likely than African Americans to receive transfers.

\section{Findings: Impediments to Mobility in Young Adulthood}

Consistent with our expectations, the Mexican Americans in our sample faced more impediments to mobility in young adulthood than non-Latino whites and comparable numbers of impediments to African Americans. Table 3 includes results from three negative binomial models that predict the number of negative outcomes respondents had experienced by young adulthood; both models show that Mexican Americans and African Americans experienced significantly more negative outcomes than whites. Model 1 is a base model that includes controls for race, gender, age, region, and urban residence. The strength of the control variables is consistent with segmented assimilation work; for example, males face significantly more impediments than females. Model 2 adds parental SES characteristics to the base model; findings suggest that higher parental SES is associated with respondents experiencing fewer impediments to mobility. Model 3 adds childhood family structure to explore whether these affect the basic patterns shown in model 1. Adding family controls in model 2 significantly reduces the strength of the Mexican American and African American coefficients; a Cox test indicates that this difference is significant, suggesting that childhood poverty and family structure affect young adult status. Although our results are consistent with those reported by Haller, 
Table 3. Impediments to Mobility: Negative Binomial Regression Models

\begin{tabular}{|c|c|c|c|}
\hline & Base model & Add parental SES & Add family controls \\
\hline Mexican American & $\begin{array}{l}0.23 * * * \\
(0.03)\end{array}$ & $\begin{array}{l}0.13 * * * \\
(0.03)\end{array}$ & $\begin{array}{l}0.07 * \\
(0.03)\end{array}$ \\
\hline African American & $\begin{array}{l}0.22 * * * \\
(0.02)\end{array}$ & $\begin{array}{l}0.15 * * * \\
(0.02)\end{array}$ & $\begin{array}{l}0.06 * \\
(0.01)\end{array}$ \\
\hline Puerto Rican & $\begin{array}{l}0.31 * * * \\
(0.06)\end{array}$ & $\begin{array}{l}0.17 * * \\
(0.06)\end{array}$ & $\begin{array}{c}0.07 \\
(0.06)\end{array}$ \\
\hline Cuban & $\begin{array}{l}-0.33 * * \\
(0.12)\end{array}$ & $\begin{array}{l}-0.37 * * \\
(0.12)\end{array}$ & $\begin{array}{l}-0.37 * * \\
(0.12)\end{array}$ \\
\hline $\begin{array}{l}\text { Father high school } \\
\text { graduate }\end{array}$ & - & $\begin{array}{l}-0.09 * * * \\
(0.02)\end{array}$ & $\begin{array}{l}-0.08 * * \\
(0.02)\end{array}$ \\
\hline $\begin{array}{l}\text { Mother high school } \\
\text { graduate }\end{array}$ & - & $\begin{array}{l}-0.15 * * * \\
(0.02)\end{array}$ & $\begin{array}{l}-0.13 * * * \\
(0.02)\end{array}$ \\
\hline $\begin{array}{l}\text { Parents' income } \\
(\log )\end{array}$ & - & $\begin{array}{l}0.00 * * * \\
(0.00)\end{array}$ & $\begin{array}{l}0.00 * * * \\
(0.00)\end{array}$ \\
\hline \multicolumn{4}{|l|}{ Childhood family } \\
\hline Stepparent family & - & - & $\begin{array}{l}0.22 * * * \\
(0.03)\end{array}$ \\
\hline $\begin{array}{l}\text { Single-parent } \\
\text { family }\end{array}$ & - & - & $\begin{array}{l}0.16 * * * \\
(0.02)\end{array}$ \\
\hline Number of siblings & - & - & $\begin{array}{l}0.03 * * * \\
(0.00)\end{array}$ \\
\hline $\begin{array}{l}\text { Extended family } \\
\text { members (no.) }\end{array}$ & - & - & $\begin{array}{l}0.05 * * * \\
(0.01)\end{array}$ \\
\hline Moved frequently & - & - & $\begin{array}{l}-0.12 \\
(0.09)\end{array}$ \\
\hline Age & $\begin{array}{l}0.02 * * * \\
(0.00)\end{array}$ & $\begin{array}{l}0.01 * * \\
(0.00)\end{array}$ & $\begin{array}{l}0.02 * * * \\
(0.00)\end{array}$ \\
\hline Male & $\begin{array}{l}0.07 * * * \\
(0.02)\end{array}$ & $\begin{array}{l}0.09 * * * \\
(0.02)\end{array}$ & $\begin{array}{l}0.09 * * * \\
(0.02)\end{array}$ \\
\hline \multicolumn{4}{|l|}{ Region of residence } \\
\hline North Central & $\begin{array}{l}0.13 * * * \\
(0.03)\end{array}$ & $\begin{array}{l}0.14 * * * \\
(0.03)\end{array}$ & $\begin{array}{l}0.12 * * * \\
(0.03)\end{array}$ \\
\hline South & $\begin{array}{c}0.05 \\
(0.03)\end{array}$ & $\begin{array}{l}0.01 * * \\
(0.03)\end{array}$ & $\begin{array}{c}0.01 \\
(0.03)\end{array}$ \\
\hline West & $\begin{array}{l}0.17 * * * \\
(0.03)\end{array}$ & $\begin{array}{l}0.15 * * * \\
(0.03)\end{array}$ & $\begin{array}{l}0.13 * * * \\
(0.03)\end{array}$ \\
\hline Urban & $\begin{array}{c}-0.04 \\
(0.02)\end{array}$ & $\begin{array}{c}-0.01 \\
(0.02)\end{array}$ & $\begin{array}{c}-0.01 \\
(0.02)\end{array}$ \\
\hline
\end{tabular}

Note: Standard errors are in parentheses.

${ }^{* * *} p<0.001{ }^{* *} p<0.01 * p<0.05$ 
Portes, and Lynch (2011), there are three important differences between our study and theirs. First, Haller and his coauthors used a more contemporary sample, the Children of Immigrants Longitudinal Study (CILS), to study these outcomes. Our respondents were young adults in a different era and encountered different circumstances than those in the CILS sample; we expect that many of our respondents or their parents obtained legal status through IRCA amnesty, an option that is not presently available to today's Mexican immigrants. However, using longitudinal data usually necessitates drawing conclusions from a sample that is not perfectly representative of current conditions. Perhaps more important, the similarity in the scores between the NLSY and CILS respondents on this measure suggests important parallels between the samples that underscore the benefits of using the NLSY. Second, Haller, Portes, and Lynch compared immigrant groups to one another. We focus on comparisons of Mexican Americans with whites and African Americans because we want to situate Mexican Americans in the larger US wealth distribution relative to the largest native-born groups. Finally, our study goes beyond outcomes in young adulthood to examine whether early impediments affect wealth outcomes in later life, offering a test of the downward mobility hypothesis over the life course.

\section{Findings: Early Disadvantage and Adult Wealth Attainment}

Patterns of midlife homeownership and wealth attainment indicate that despite experiencing impediments to mobility, Mexican Americans attain significant wealth by adulthood. Table 4 includes estimates from nested logistic regression models of homeownership and separates Mexican Americans by generation since migration in all models because broader ethnic patterns in homeownership are well documented (Myers, Megbolugbe, and Lee 1998). In model 1, we control for basic demographic characteristics. Consistent with our expectations, results indicate that regardless of generation since immigration, Mexican Americans are less likely than non-Latino whites but more likely than African Americans to be homeowners at midlife. When we compare first-, second-, and third-generation individuals in this cohort, third-generation Mexican Americans are more likely than the first and second generations to own homes. In model 2, we investigate how early life conditions affect adult homeownership by adding indicators of childhood poverty and young adult impediments to mobility. Respondents who experienced childhood poverty or reported impediments to mobility as a young adult were less likely to own homes in midlife. However, adding these variables does not change the original finding that Mexican Americans are less likely than non-Latino whites and more likely than African Americans to own homes.

When we control for education in model 3 , there is no longer a significant difference between non-Latino whites and first- and third-generation Mexican American homeownership. This means that, consistent with findings from the wealth mobility literature, educational attainment is a very important explanatory factor in homeownership differences between non-Latino whites and 
Table 4. Midlife Homeownership: Logistic Regression of Homeownership in 2008

\begin{tabular}{|c|c|c|c|c|}
\hline & Model 1 & Model 2 & Model 3 & Model 4 \\
\hline \multicolumn{5}{|l|}{ Mexican American } \\
\hline First generation & $\begin{array}{l}-0.62 * * * \\
(0.16)\end{array}$ & $\begin{array}{l}-0.34 * \\
(0.16)\end{array}$ & $\begin{array}{l}-0.15 \\
(0.17)\end{array}$ & $\begin{array}{l}-0.11 \\
(0.20)\end{array}$ \\
\hline $\begin{array}{l}\text { Second } \\
\text { generation }\end{array}$ & $\begin{array}{l}-0.57 * * * \\
(0.15)\end{array}$ & $\begin{array}{c}-0.38 * \\
(0.16)\end{array}$ & $\begin{array}{l}-0.35 * \\
(0.16)\end{array}$ & $\begin{array}{l}-0.28 \\
(0.19)\end{array}$ \\
\hline $\begin{array}{l}\text { Third generation } \\
\text { plus }\end{array}$ & $\begin{array}{l}-0.55 * * * \\
(0.13)\end{array}$ & $\begin{array}{l}-0.35 * * \\
(0.13)\end{array}$ & $\begin{array}{l}-0.25 \\
(0.13)\end{array}$ & $\begin{array}{l}-0.22 \\
(0.16)\end{array}$ \\
\hline Puerto Rican & $\begin{array}{l}-1.53 * * * \\
(0.16)\end{array}$ & $\begin{array}{l}-1.30 * * * \\
(0.16)\end{array}$ & $\begin{array}{l}-1.21 * * * \\
(0.16)\end{array}$ & $\begin{array}{l}-0.88 * * * \\
(0.20)\end{array}$ \\
\hline Cuban & $\begin{array}{l}-0.51 \\
(0.27)\end{array}$ & $\begin{array}{c}-0.58 * \\
(0.28)\end{array}$ & $\begin{array}{l}-0.54 \\
(0.28)\end{array}$ & $\begin{array}{l}-0.49 \\
(0.33)\end{array}$ \\
\hline African American & $\begin{array}{l}-1.36 * * * \\
(0.06)\end{array}$ & $\begin{array}{l}-1.20 * * * \\
(0.07)\end{array}$ & $\begin{array}{l}-1.19 * * * \\
(0.07)\end{array}$ & $\begin{array}{l}-0.83 * * * \\
(0.09)\end{array}$ \\
\hline $\begin{array}{l}\text { Childhood } \\
\text { poverty }\end{array}$ & - & $\begin{array}{l}-0.29 * * * \\
(0.07)\end{array}$ & $\begin{array}{l}-0.20 * * \\
(0.07)\end{array}$ & $\begin{array}{l}-0.11 \\
(0.08)\end{array}$ \\
\hline $\begin{array}{l}\text { Impediments to } \\
\text { mobility }\end{array}$ & - & $\begin{array}{l}-0.29 * * * \\
(0.02)\end{array}$ & $\begin{array}{l}-0.20 * * * \\
(0.02)\end{array}$ & $\begin{array}{l}-0.16 * * * \\
(0.03)\end{array}$ \\
\hline $\begin{array}{l}\text { Inheritance } \\
\text { receipt }\end{array}$ & - & - & - & $\begin{array}{c}0.18 * \\
(0.08)\end{array}$ \\
\hline \multicolumn{5}{|l|}{ Education } \\
\hline High school & - & - & $\begin{array}{l}0.22 * * \\
(0.08)\end{array}$ & $\begin{array}{c}0.08 \\
(0.12)\end{array}$ \\
\hline Some college & - & - & $\begin{array}{l}0.58 * * * \\
(0.09)\end{array}$ & $\begin{array}{l}0.28 * \\
(0.14)\end{array}$ \\
\hline College degree & - & - & $\begin{array}{l}1.29 * * * \\
(0.13)\end{array}$ & $\begin{array}{l}0.89 * * * \\
(0.17)\end{array}$ \\
\hline $\begin{array}{l}\text { Advanced } \\
\text { degree }\end{array}$ & - & - & $\begin{array}{l}1.19 * * * \\
(0.14)\end{array}$ & $\begin{array}{l}0.64 * * * \\
(0.18)\end{array}$ \\
\hline $\begin{array}{l}\text { Household } \\
\text { income (log) }\end{array}$ & - & - & - & $\begin{array}{l}0.30 * * * \\
(0.03)\end{array}$ \\
\hline \multicolumn{5}{|l|}{ Adult family } \\
\hline $\begin{array}{l}\text { Number of } \\
\text { children }\end{array}$ & - & - & - & $\begin{array}{l}0.37 * * * \\
(0.07)\end{array}$ \\
\hline $\begin{array}{l}\text { Number of } \\
\text { children squared }\end{array}$ & - & - & - & $\begin{array}{l}-0.06 * * * \\
(0.02)\end{array}$ \\
\hline
\end{tabular}


Table 4. continued

\begin{tabular}{|c|c|c|c|c|}
\hline & Model 1 & Model 2 & Model 3 & Model 4 \\
\hline Married & - & - & - & $\begin{array}{l}1.28 * * * \\
(0.10)\end{array}$ \\
\hline Separated & - & - & - & $\begin{array}{c}-0.08 \\
(0.16)\end{array}$ \\
\hline Divorced & - & - & - & $\begin{array}{l}0.36 * * * \\
(0.11)\end{array}$ \\
\hline Widowed & - & - & - & $\begin{array}{c}0.71 * \\
(0.29)\end{array}$ \\
\hline Age & $\begin{array}{c}-0.45 \\
(0.30)\end{array}$ & $\begin{array}{r}-0.42 \\
(0.30)\end{array}$ & $\begin{array}{c}-0.44 \\
(0.31)\end{array}$ & $\begin{array}{c}-0.51 \\
(0.37)\end{array}$ \\
\hline Age squared & $\begin{array}{c}0.01 \\
(0.01)\end{array}$ & $\begin{array}{c}0.01 \\
(0.06)\end{array}$ & $\begin{array}{c}0.01 \\
(0.01)\end{array}$ & $\begin{array}{c}0.01 \\
(0.01)\end{array}$ \\
\hline Male & $\begin{array}{l}-0.15 * * \\
(0.05)\end{array}$ & $\begin{array}{c}-0.14 * \\
(0.06)\end{array}$ & $\begin{array}{c}-0.08 \\
(0.06)\end{array}$ & $\begin{array}{l}-0.00 \\
(0.07)\end{array}$ \\
\hline \multicolumn{5}{|c|}{ Region of residence } \\
\hline North Central & $\begin{array}{l}0.20 * \\
(0.09)\end{array}$ & $\begin{array}{l}0.27^{* * *} \\
(0.09)\end{array}$ & $\begin{array}{l}0.30 * * \\
(0.09)\end{array}$ & $\begin{array}{l}0.41 * * * \\
(0.11)\end{array}$ \\
\hline South & $\begin{array}{l}0.26 * * * \\
(0.08)\end{array}$ & $\begin{array}{l}0.30 * * * \\
(0.08)\end{array}$ & $\begin{array}{l}0.35 * * * \\
(0.08)\end{array}$ & $\begin{array}{l}0.45^{* * *} \\
(0.10)\end{array}$ \\
\hline West & $\begin{array}{c}-0.11 \\
(0.10)\end{array}$ & $\begin{array}{c}-0.06 \\
(0.10)\end{array}$ & $\begin{array}{c}-0.06 \\
(0.10)\end{array}$ & $\begin{array}{c}0.06 \\
(0.12)\end{array}$ \\
\hline Urban & $\begin{array}{l}-0.16^{* *} \\
(0.06)\end{array}$ & $\begin{array}{l}-0.18 * * \\
(0.06)\end{array}$ & $\begin{array}{l}-0.20 * * \\
(0.07)\end{array}$ & $\begin{array}{l}-0.16 \\
(0.08)\end{array}$ \\
\hline
\end{tabular}

Note: Standard errors are in parentheses.

${ }^{* * *} p<0.001{ }^{* *} p<0.01 * p<0.05$

first- and third-generation Mexican Americans. This supports our argument that educational gains are key predictors of Mexican American homeownership and, more generally, class mobility. This also suggests that, despite some uncertainty in the assimilation literature regarding educational attainment as an outcome or a mechanism leading to upward mobility, in reference to wealth, education appears to be a clear mechanism. In contrast, second-generation Mexican Americans are still less likely to own homes in model 3, meaning that regardless of early life obstacles or educational attainment, they are less likely to be homeowners than non-Latino whites. In model 4, we control for income, marital status, and fertility. When we add family controls to the model, there are no longer any significant differences between Mexican American and nonLatino white homeownership, although African Americans remain less likely than non-Latino whites to own homes. Consistent with previous research on 
wealth inequality, these results suggest that homeownership plays a central role in Mexican Americans upward mobility and African American wealth stagnation (Shapiro, Meschede, and Osoro 2013).

Due in part to the fact that home equity comprises a large portion of US wealth, the midlife wealth status of Mexican Americans reflects their midlife homeownership patterns. Table 5 includes results of GLS models of total 2008 net worth. Modeling 2004 or 2010 wealth generated similar results substantively, but net worth levels were artificially low in the 2010 data as a result of the economic recession. Similar to table 4, we specify immigrant generation in each model of table 5 and nest the GLS models so that we can examine the cumulative effects of young adult conditions, education, income, family characteristics, inheritances, and earlier homeownership on adult wealth. In model 1, we include basic demographic characteristics; our findings indicate that Mexican Americans-regardless of generation-have higher midlife wealth than African Americans and less than non-Latino whites. However, comparing the wealth of first-, second-, and third-generation individuals within this cohort adds nuances to these findings: with each generation, Mexican American midlife wealth is closer to, although still significantly less than, non-Latino white wealth. In other words, the midlife wealth of third-generation Mexican Americans in this cohort is closer to that of non-Latino whites than first- or second-generation Mexican Americans, which might indicate a pattern of delayed assimilation for third-generation Mexican Americans in this birth cohort. These findings are consistent with research showing that the consumption and saving patterns of second- and third-generation immigrant households more closely resemble those of non-Latino whites (Yang and Solheim 2007), in part because they have fewer financial obligations to kin in the United States and abroad (Agius Vallejo 2012; Soehl and Waldinger 2012).

Model 2 adds controls for childhood poverty and young adulthood impediments to mobility. Although these predictors do not explain differences in midlife wealth between Mexican Americans and non-Latino whites, they both are associated with decreased wealth in adulthood. This makes intuitive sense: we would expect SES conditions during childhood and young adulthood to affect adult SES, especially in the absence of other important wealth predictors such as education or family processes. When we do add indicators of education, income, fertility, and marriage in model 3, childhood poverty and young adult impediments to mobility have a much smaller, but still significant, effect on adult wealth. Even after adding these controls, Mexican Americans continue to have lower midlife wealth than non-Latino whites. Consistent with our expectation, education is a powerful predictor of owning greater adult wealth in our sample. In model 4, we add an indicator of inheritance receipt. Findings from this model indicate that individuals who received inheritances have significantly higher adult wealth; however, our substantive results regarding Mexican American wealth are unchanged by this addition. In our final model, we include a measure of homeownership a decade earlier (1998). Owning a home during the past decade is associated with significantly higher midlife wealth in our sample, and in model 5 there is no longer a significant difference in the midlife wealth 
Table 5. Midlife Wealth Attainment: GLS Models of Net Worth in 2008 (age 43-51)

\begin{tabular}{|c|c|c|c|c|c|}
\hline & Model 1 & Model 2 & Model 3 & Model 4 & Model 5 \\
\hline \multicolumn{6}{|l|}{ Mexican American } \\
\hline \multirow[t]{2}{*}{ First generation } & $-0.23 * * *$ & $-0.17 * * *$ & $-0.08 *$ & -0.05 & $-0.10 * *$ \\
\hline & $(0.04)$ & $(0.04)$ & $(0.04)$ & $(0.04)$ & $(0.04)$ \\
\hline \multirow{2}{*}{$\begin{array}{l}\text { Second } \\
\text { generation }\end{array}$} & $-0.21 * * *$ & $-0.17 * * *$ & $-0.15 * * *$ & $-0.12 * *$ & $-0.11 * *$ \\
\hline & $(0.03)$ & $(0.03)$ & $(0.05)$ & $(0.04)$ & $(0.04)$ \\
\hline \multirow{2}{*}{$\begin{array}{l}\text { Third } \\
\text { generation plus }\end{array}$} & $-0.20 * * *$ & $-0.15 * * *$ & $-0.09 * *$ & $-0.07^{*}$ & -0.06 \\
\hline & $(0.03)$ & $(0.03)$ & $(0.03)$ & $(0.03)$ & $(0.03)$ \\
\hline \multirow[t]{2}{*}{ African American } & $-0.26 * * *$ & $-0.21 * * *$ & $-0.12 * * *$ & $-0.09 * * *$ & $-0.09 * * *$ \\
\hline & $(0.01)$ & $(0.01)$ & $(0.02)$ & $(0.02)$ & $(0.02)$ \\
\hline \multirow[t]{2}{*}{ Puerto Rican } & $0.28 * * *$ & $-0.22 * * *$ & $-0.13 * *$ & $-0.10 * *$ & $-0.09 *$ \\
\hline & $(0.04)$ & $(0.04)$ & $(0.04)$ & $(0.04)$ & $(0.04)$ \\
\hline \multirow[t]{2}{*}{ Cuban } & -0.01 & -0.02 & 0.05 & 0.05 & 0.05 \\
\hline & $(0.06)$ & $(0.06)$ & $(0.06)$ & $(0.06)$ & $(0.06)$ \\
\hline \multirow{2}{*}{$\begin{array}{l}\text { Childhood } \\
\text { poverty }\end{array}$} & - & $-0.08 * * *$ & $-0.03 *$ & -0.03 & -0.03 \\
\hline & & $(0.02)$ & $(0.02)$ & $(0.02)$ & $(0.02)$ \\
\hline \multirow{2}{*}{$\begin{array}{l}\text { Impediments to } \\
\text { mobility }\end{array}$} & - & $-0.06 * * *$ & $-0.01 *$ & $-0.01^{*}$ & -0.01 \\
\hline & & $(0.00)$ & $(0.01)$ & $(0.01)$ & $(0.01)$ \\
\hline \multirow{2}{*}{$\begin{array}{l}\text { Inheritance } \\
\text { receipt }\end{array}$} & - & - & - & $0.10 * * *$ & $0.09 * * *$ \\
\hline & & & & $(0.01)$ & $(0.01)$ \\
\hline \multirow{2}{*}{$\begin{array}{l}\text { Homeowner in } \\
1998\end{array}$} & - & - & - & - & $0.13 * * *$ \\
\hline & & & & & $(0.01)$ \\
\hline \multicolumn{6}{|l|}{ Education } \\
\hline \multirow[t]{2}{*}{ High school } & - & - & $0.06 * *$ & $0.06^{*}$ & 0.04 \\
\hline & & & $(0.02)$ & $(0.02)$ & $(0.02)$ \\
\hline \multirow[t]{2}{*}{ Some college } & - & - & $0.13 * * *$ & $0.11 * * *$ & $0.09 * * *$ \\
\hline & & & $(0.03)$ & $(0.03)$ & $(0.03)$ \\
\hline \multirow[t]{2}{*}{ College degree } & - & - & $0.30 * * *$ & $0.27 * * *$ & $0.24 * * *$ \\
\hline & & & $(0.03)$ & $(0.03)$ & $(0.03)$ \\
\hline \multirow{2}{*}{$\begin{array}{l}\text { Advanced } \\
\text { degree }\end{array}$} & - & - & $0.34 * * *$ & $0.30 * * *$ & $0.27 * * *$ \\
\hline & & & $(0.03)$ & $(0.03)$ & $(0.03)$ \\
\hline \multirow{2}{*}{$\begin{array}{l}\text { Household } \\
\text { income (log) }\end{array}$} & - & - & $0.04 * * *$ & $0.04 * * *$ & $0.04 * * *$ \\
\hline & & & $(0.00)$ & $(0.00)$ & $(0.00)$ \\
\hline \multicolumn{6}{|l|}{ Adult family } \\
\hline \multirow{2}{*}{$\begin{array}{l}\text { Number of } \\
\text { children }\end{array}$} & - & - & 0.02 & 0.02 & 0.01 \\
\hline & & & $(0.01)$ & $(0.01)$ & $(0.01)$ \\
\hline
\end{tabular}


Table 5. continued

\begin{tabular}{|c|c|c|c|c|c|}
\hline & Model 1 & Model 2 & Model 3 & Model 4 & Model 5 \\
\hline $\begin{array}{l}\text { Number of } \\
\text { children squared }\end{array}$ & - & - & $\begin{array}{l}-0.01 \\
(0.00)\end{array}$ & $\begin{array}{l}-0.01 \\
(0.00)\end{array}$ & $\begin{array}{l}-0.00 \\
(0.00)\end{array}$ \\
\hline Married & - & - & $\begin{array}{l}0.13 * * * \\
(0.02)\end{array}$ & $\begin{array}{l}0.13 * * * \\
(0.02)\end{array}$ & $\begin{array}{l}0.08 * * * \\
(0.02)\end{array}$ \\
\hline Separated & - & - & $\begin{array}{l}-0.02 \\
(0.03)\end{array}$ & $\begin{array}{l}-0.01 \\
(0.03)\end{array}$ & $\begin{array}{l}-0.03 \\
(0.03)\end{array}$ \\
\hline Divorced & - & - & $\begin{array}{c}0.01 \\
(0.04)\end{array}$ & $\begin{array}{c}0.01 \\
(0.02)\end{array}$ & $\begin{array}{l}-0.01 \\
(0.02)\end{array}$ \\
\hline Widowed & - & - & $\begin{array}{c}0.04 \\
(0.06)\end{array}$ & $\begin{array}{c}0.03 \\
(0.06)\end{array}$ & $\begin{array}{c}0.00 \\
(0.06)\end{array}$ \\
\hline Age & $\begin{array}{c}0.01 \\
(0.06)\end{array}$ & $\begin{array}{c}0.02 \\
(0.06)\end{array}$ & $\begin{array}{l}-0.01 \\
(0.07)\end{array}$ & $\begin{array}{l}-0.01 \\
(0.07)\end{array}$ & $\begin{array}{l}-0.03 \\
(0.07)\end{array}$ \\
\hline $\mathrm{Age}^{2}$ & $\begin{array}{l}-0.00 \\
(0.00)\end{array}$ & $\begin{array}{l}-0.00 \\
(0.00)\end{array}$ & $\begin{array}{c}0.00 \\
(0.00)\end{array}$ & $\begin{array}{c}0.00 \\
(0.00)\end{array}$ & $\begin{array}{c}0.00 \\
(0.00)\end{array}$ \\
\hline Male & $\begin{array}{l}0.03 * * \\
(0.01)\end{array}$ & $\begin{array}{l}0.04 * * \\
(0.01)\end{array}$ & $\begin{array}{l}0.05 * * * \\
(0.01)\end{array}$ & $\begin{array}{l}0.05 * * * \\
(0.01)\end{array}$ & $\begin{array}{l}0.05 * * * \\
(0.01)\end{array}$ \\
\hline \multicolumn{6}{|c|}{ Region of residence } \\
\hline North Central & $\begin{array}{l}-0.08 * * * \\
(0.01)\end{array}$ & $\begin{array}{l}-0.06 * * * \\
(0.02)\end{array}$ & $\begin{array}{c}-0.05^{*} \\
(0.02)\end{array}$ & $\begin{array}{c}-0.05^{*} \\
(0.02)\end{array}$ & $\begin{array}{l}-0.06 * * \\
(0.02)\end{array}$ \\
\hline \multirow[t]{2}{*}{ South } & $-0.06 * * *$ & $-0.05 *$ & $-0.04 *$ & -0.03 & $-0.05 *$ \\
\hline & $(0.02)$ & $(0.02)$ & $(0.02)$ & $(0.02)$ & $(0.02)$ \\
\hline \multirow[t]{2}{*}{ West } & -0.03 & -0.02 & -0.01 & 0.00 & -0.02 \\
\hline & $(0.02)$ & $(0.02)$ & $(0.02)$ & $(0.02)$ & $(0.02)$ \\
\hline \multirow[t]{2}{*}{ Urban } & $0.05 * * *$ & $0.05 * * *$ & $0.04 * *$ & $0.04 *$ & $0.04 * *$ \\
\hline & $(0.01)$ & $(0.01)$ & $(0.01)$ & $(0.01)$ & $(0.01)$ \\
\hline
\end{tabular}

Note: Dependent variable is net worth or total assets less total debts; it is logged using the natural $\log$ and divided by 1,000 . Standard errors are in parentheses.

*** $p<0.001{ }^{* *} p<0.01 * p<0.05$

of third-generation Mexican Americans and non-Latino whites. Additionally, in our final model, owning a home in 1998 mediates the negative relationship between impediments to mobility and midlife wealth, suggesting that early asset accumulation can help overcome young adult impediments to mobility in attaining greater midlife wealth. Taken together, findings from tables 4 and 5 suggest that although Mexican Americans in this cohort sample do not reach wealth parity with non-Latino whites, by midlife they are more likely to own homes and attain higher wealth than African Americans, despite the prevalence of early life disadvantages among both groups. 


\section{Conclusion}

This study explored the wealth mobility patterns of Mexican Americans to provide insight into theoretical debates about immigrant assimilation prospects. We integrated ideas from immigrant attainment and wealth mobility research to develop propositions regarding Mexican American wealth mobility. We contributed to these literatures by demonstrating that mobility is a process that occurs across the life course and that is best understood when early life, adolescence, and adulthood are studied together. We tested these ideas using longitudinal data from a relatively large cohort sample that allowed us to observe starting points, young adult processes, and midlife wealth for respondents who are now adult Mexican Americans. Although our sample is not representative of current cross-sections of Mexican Americans, using a cohort sample allowed us to study life-course trajectories that are relevant to understanding today's immigrants. Consistent with mainstream assimilation scholars' concept of delayed assimilation, our results showed that Mexican Americans in this cohort experienced upward wealth mobility over their lives, but they do not achieve parity with whites. We found high levels of childhood poverty and low levels of inheritance when we compared Mexican Americans with non-Latino whites, but we also found that these disadvantages are smaller when comparing first-, second-, and third-generation respondents. In addition, our results suggested that Mexican Americans overall had levels of childhood poverty and inheritances that were relatively similar to those of African Americans; however, we found that second- and later-generation Mexican Americans were less likely than African Americans to be raised in poverty and more likely to receive transfers.

Segmented assimilation scholars examine Mexican Americans in young adulthood and conclude that early impediments will ensure their downward mobility and later life poverty. However, these scholars study Mexican American young adults who have not yet aged into midlife. Our research uses an identical index constructed when our respondents were 24 years old, the same age as the respondents used by segmented assimilation scholars, but our research goes further by examining Mexican Americans at three points in the life courseearly life, young adulthood, and midlife-allowing us to measure whether early impediments truncate wealth mobility over the life course and whether they affect later life outcomes. Mexican Americans in this cohort do not reach wealth parity with whites, but they attain higher levels of wealth by midlife than African Americans, despite the prevalence of early life disadvantage. Notably, Mexican Americans in our sample encountered more impediments to mobility in young adulthood than whites and comparable numbers of impediments to African Americans, but despite these early disadvantages, Mexican Americans were upwardly mobile over the life course, achieving high rates of net worth and homeownership at midlife. This finding is a particularly important contribution to the literature because it provides a direct rebuttal to segmented assimilation research, which argues that deviant young adult behaviors result in downward mobility (Haller, Portes, and Lynch 2011). Overall, our findings demonstrate 
that despite early impediments, Mexican Americans attain significant wealth by midlife, including higher homeownership rates and levels of net worth than African Americans, suggesting that predictions of Mexican American downward mobility are overestimated.

However, there are reasons to be cautious about these findings. Although our data have important advantages, they are not perfect. Following a cohort over 30 years allowed us to highlight long-term trends in wealth mobility that have been absent in the immigrant assimilation literature, but this cohort is unique in important ways. The sample was taken before recent waves of immigration, and the respondents experienced different social, economic, and political realities than a comparable sample taken today would encounter. For example, the respondents in our sample grew up in an era when legalization pathways, such as the 1986 amnesty under IRCA, were available to the first generation and helped stabilize families economically and provided access to education. We were unable to examine whether and to what extent legal status facilitates wealth accumulation, but there is evidence that legalization is an important mechanism that leads to greater economic stability among the first generation, helping expedite the mobility of the second generation (Agius Vallejo 2012; Bean et al. 2011). All of these factors can facilitate saving, wealth accumulation, and upward mobility, underscoring the importance of legal status and raising important questions about the ability of post-1986 unauthorized Mexican immigrants and their descendants to accumulate wealth. It is also likely that the Mexican Americans sampled in our data are self-selected to some degree. Specifically, undocumented immigrants are less likely to be respondents, while third-generation Mexican Americans may be less likely to self-report as Mexican Americans.

Our findings do not imply that all Mexican Americans are becoming wealthy or are immune to financial insecurity. Instead, our results support mainstream assimilation theories by suggesting that Mexican Americans are not uniformly entering the underclass; however, we identified multiple mobility trajectories within the larger Mexican American group, including by generation within the same cohort, suggesting that the mobility process is nuanced within the Mexican American community. Moreover, although we find evidence of both inter- and intragenerational mobility, our results also indicate that Mexican Americans have not reached economic parity with whites, suggesting that they are experiencing delayed assimilation, where widespread convergence to the middle-class mean may take several generations (Bean 2011). In addition to legalization, Mexican Americans continue to face other challenges, and our results should not be read as indicating otherwise. For example, Mexican Americans of all generations continue to face educational challenges and discrimination, particularly in low-wage labor markets (Pager, Bonikowski, and Western 2009; Pager and Quillian 2005). Our findings demonstrate the salience of education for creating wealth mobility, and policymakers and researchers should continue to address the Mexican American educational gap, as education is the single most important variable that increases midlife wealth.

Indeed, Mexican Americans' unique position within the US racial stratification hierarchy may prevent them from ever reaching wealth parity with whites, 
while still allowing them greater opportunities for mobility compared to African Americans. Contemporary Mexican Americans experience a negative social context that can criminalize their ethnic group, but because theirs is a history of immigration (not colonization or slavery), viewing them as akin to African Americans excludes temporal changes that have facilitated mobility among today's new immigrants (Jiménez and Fitzgerald 2007). However, it is likely that some of the factors that contribute to slower wealth accumulation among African Americans (e.g., residential segregation, predatory lending) at least partially affect Mexican Americans and may prevent them from reaching wealth parity with whites (Oliver and Shapiro 1995). Our findings have direct implications for immigrant assimilation theories by refuting the assumption that early impediments lead to downward mobility over the life course. We find evidence that Mexican Americans who have had sufficient time and stability to accumulate wealth have done so and are creating an asset base that can be transferred across generations to promote middle-class entry for their descendants, resulting in long-term class stability. These benefits have far-reaching implications; as the second- and later-generation Mexican American population grows and baby boomers retire, Mexican Americans will comprise a larger portion of the US population and workforce.

\section{Note}

1. We code 1.5-generation respondents as first generation because we do not know age at immigration. Third generation includes third generation plus; we refer to them as third generation from here forward.

\section{About the Authors}

Lisa A. Keister is the Gilhuly Family Professor of Sociology at Duke University. She conducts research on wealth ownership in the United States, the one percent, the role of religion in economic decision-making, immigration and its economic consequences, and organizational startup and performance during China's transition. She is the author of numerous books and articles, including Wealth in America (2000), Getting Rich (2005), and Faith and Money: How Religious Belief Contributes to Wealth and Poverty (2011).

Jody Agius Vallejo is an Assistant Professor of Sociology at the University of Southern California. Her research examines immigrant integration, race/ethnicity, the Latino middle and upper class, Latino philanthropy, and Latino entrepreneurs. She is the author of Barrios to Burbs: The Making of the Mexican American Middle Class (Stanford University Press, 2012).

E. Paige Borelli is a PhD candidate in sociology at Duke University. Borelli's research interests include immigrant economic and health outcomes and Chinese society; her research on these topics has been published in Sociological Perspectives and in various book chapters. Borelli's current research explores the distribution of foreign asset ownership among US immigrants and investigates how including these assets in calculations of wealth can provide important insights into the stratification patterns of contemporary immigrants. 


\section{References}

Agius Vallejo, Jody. 2009. "Latina Spaces: Middle-Class Ethnic Capital and Professional Associations in the Latino Community." City and Community 8:129-54.

2012. Barrios to Burbs: The Making of the Mexican-American Middle Class. Palo Alto, CA: Stanford University Press.

Alba, Richard. 2008. "Why We Still Need a Theory of Mainstream Assimilation." Kolner Zeitschrift fur Soziologie und Sozialpsychologie 48(special issue):37-56.

2009. Blurring the Color Line: The New Chance for a More Integrated America. Cambridge, MA: Harvard University Press.

Alba, Richard, Tomás R. Jiménez, and Helen Marrow. 2013. “Mexican Americans as a Paradigm for Contemporary Intragroup Heterogeneity." Ethnic and Racial Studies 37:446-66.

Alba, Richard, Philip Kasinitz, and Mary C. Waters. 2011. “The Kids Are (Mostly) Alright: Second-Generation Assimilation." Social Forces 89:763-74.

Alba, Richard D., and John R. Logan. 1992. "Assimilation and Stratification in the Homeownership Patterns of Different Racial and Ethnic Groups." International Migration Review Winter:1314-41.

Alba, Richard, and Victor Nee. 2003. Remaking the American Mainstream: Assimilation and Contemporary Immigration. Cambridge, MA: Harvard University Press.

Bean, Frank D., Mark A. Leach, Susan K. Brown, James D. Bachmeier, John R. Hipp. 2011. “The Educational Legacy of Unauthorized Migration: Comparisons across US Immigrant Groups in How Parents' Status Affects Their Offspring." International Migration Review 45:348-85.

Bean, Frank D., and Gillian Stevens. 2003. America's Newcomers and the Dynamics of Diversity. New York: Russell Sage Foundation.

Blau, Peter Michael, and Otis Dudley Duncan. 1967. The American Occupational Structure. New York: Wiley.

Bricker, Jesse, Arthur B. Kennickell, Kevin Moore, and John Sabelhaus. 2012. "Changes in US Family Finances from 2007 to 2010: Evidence from the Survey of Consumer Finances." Federal Reserve Bank Working Paper, http://www.federalreserve.gov/pubs/bulletin/2012/pdf/scf12.pdf.

Brown, Susan K. 2007. “Delayed Spatial Assimilation: Multigenerational Incorporation of the MexicanOrigin Population in Los Angeles." City and Community 6:193-209.

Campbell, Lori Ann, and Robert L. Kaufman. 2006. "Racial Differences in Household Wealth: Beyond Black and White." Research in Social Stratification and Mobility 24:131-52.

Charles, Kerwin Kofi, and Erik Hurst. 2002. "The Transition to Home Ownership and the Black-White Wealth Gap." Review of Economics and Statistics 84:281-97.

Chavez, Leo R. 1988. "Settlers and Sojourners: The Case of Mexicans in the United States." Human Organization 47:95-108.

Clark, Rebecca L., Jennifer E. Glick, and Regina M. Bures. 2009. "Immigrant Families over the Life Course." Journal of Family Issues 30:852-72.

Clark, William A. V. 2001. "Immigration and Hispanic Middle Class." Center for Immigration Studies (CIS) Working Paper.

Conley, Dalton. 1999. Being Black, Living in the Red: Race, Wealth and Social Policy in America. Berkeley: University of California Press.

Corcoran, M. 1995. "Rags to Rags: Poverty and Mobility in the United States." Annual Review of Sociology 21:237-67.

Elder, Glen H. 1992. "Models of the Life Course." Contemporary Sociology 21:632-35.

Emeka, Amon, and Jody Agius Vallejo. 2011. "Non-Hispanics with Latino American Ancestry: Assimilation, Race, and Identity among Latin American Descendants in the US." Social Science Research 40:1547-63. 
Feliciano, Cynthia. 2005. "Does Selective Migration Matter? Explaining Ethnic Disparities in Educational Attainment among Immigrants' Children." International Migration Review 39:841-71.

2006. Unequal Origins: Immigrant Selection and the Education of the Second Generation. New York: LFC Scholarly Publishing.

Gordon, Milton M. 1964. Assimilation in American Life: The Role of Race, Religion, and National Origin. New York: Oxford University Press.

Haller, William, Alejandro Portes, and Scott M. Lynch. 2011. “Dreams Fulfilled, Dreams Shattered: Determinants of Segmented Assimilation in the Second Generation." Social Forces 89:733-62.

Hao, Lingxin. 2007. Color Lines, Country Lines: Race, Immigration, and Wealth Stratification in America. New York: Russell Sage Foundation.

Harris, Kathleen Mullan. 1997. Teen Mothers and the Revolving Welfare Door. Philadelphia: Temple University.

Hauser, Robert M., and Peter A. Mossel. 1985. "Fraternal Resemblance in Educational Attainment and Occupational Status." American Journal of Sociology 91:650-73.

Haynie, Dana L., Scott J. South, and Sunita Bose. 2006. "The Company You Keep: Adolescent Mobility and Peer Behavior." Sociological Inquiry 76:397-426.

Henretta, John. 1984. "Parental Status and Child's Homeownership." American Sociological Review 49:131-40.

Jiménez, Tomás R., and David Fitzgerald. 2007. "Mexican Assimilation: A Temporal and Spatial Reorientation." Du Bois Review 4:337-54.

Kasinitz, Philip, John H. Mollenkopf, Mary C. Waters, and Jennifer Holdaway. 2008. Inheriting the City: The Children of Immigrants Come of Age. New York: Russell Sage Foundation.

Keister, Lisa A. 2004. "Family Structure, Race, and Wealth: The Effect of Childhood Family on Adult Asset Ownership." Sociological Perspectives 47:161-87.

2005. Getting Rich: America's New Rich and How They Got that Way. Cambridge, UK: Cambridge University Press.

2007. "Upward Wealth Mobility: Exploring the Roman Catholic Advantage." Social Forces 85:1195-1225.

2011. Faith and Money: How Religious Belief Contributes to Wealth and Poverty. Cambridge, UK: Cambridge University Press.

Kurz, Karin, and Walter Muller. 1987. "Class Mobility in the Industrial World." Annual Review of Sociology 13:417-42.

Leach, Mark A. 2013. "A Burden of Support? Household Structure and Economic Resources among Mexican Immigrant Families." Journal of Family Issues 34:28-53.

Lee, Jennifer, and Frank D. Bean. 2010. The Diversity Paradox: Immigration and the Color Line in 21stCentury America. New York: Russell Sage.

Lloyd, Kim M. 2006. "Latinas Transition to First Marriage: An Examination of Four Theoretical Perspectives." Journal of Marriage and Family 68:993-1014.

Lopez, Mark Hugo, Gretchen Livingston, and Rakesh Koshar. 2009. "Hispanics and the Economic Downturn: Housing Woes and Remittance Cuts." Washington, DC: Pew Hispanic Center.

Massey, Douglas, Jorge Durand, and Nolan Malone. 2003. Beyond Smoke and Mirrors: Mexican Immigration in an Era of Economic Integration. New York: Russell Sage Foundation.

Motel, Seth, and Eileen Patten. 2012. "The 10 Largest Hispanic Origin Groups: Characteristics, Rankings, Top Counties." Washington, DC: Pew Hispanic Center.

Myers, Dowell. 2008. Immigrants and Boomers: Forging a New Social Contract for the Future of America. New York: Russell Sage Foundation.

Myers, Dowell, and Seong Woo Lee. 1998. "Immigrant Trajectories into Homeownership: A Temporal Analysis of Residential Assimilation." International Migration Review 32:593-625. 
Myers, Dowell, Isaac Megbolugbe, and Seong Woo Lee. 1998. "Cohort Estimation of Homeownership Attainment among Native-Born and Immigrant Populations." Journal of Housing Research 9:237-69.

Oliver, Melvin L., and Thomas M. Shapiro. 1995. Black Wealth/White Wealth: A New Perspective on Racial Inequality. New York: Routledge.

O'Rand, Angela M., and Margaret L. Krecker. 1990. "Concepts of the Life Cycle: Their History, Meanings, and Uses in the Social Sciences." Annual Review of Sociology 16:241-62.

Ortmeyer, David L., and Michael A. Quinn. 2012. "Coyotes, Migration Duration, and Remittances." Journal of Developing Areas 46:185-203.

Pager, Devah, Bart Bonikowski, and Bruce Western. 2009. “Discrimination in a Low-Wage Labor Market: A Field Experiment." American Socioligical Review 74:777-99.

Pager, Devah, and Lincoln Quillian. 2005. "Walking the Talk: What Employers Say Versus What They Do." American Socioligical Review 70:355-80.

Park, Julie, and Dowell Myers. 2010. "Intergenerational Mobility in the Post-1965 Immigration Era: Estimates by an Immigrant Generation Cohort Method." Demography 47:369-92.

Parrado, Emilio. 2011. "How High Is Hispanic/Mexican Fertility in the United States? Immigration and Tempo Considerations “ Demography 48:1059-80.

Passel, Jeffrey S., and D’Vera Cohn. 2011. “How Many Hispanics? Comparing New Census Counts with the Latest Census Estimates." Washington, DC: Pew Hispanic Center.

Perlmann, Joel. 2005. Italians Then, Mexicans Now: Immigrant Origins and Second-Generation Progress, 1890-2000. New York: Russell Sage.

Portes, Alejandro, and Patricia Fernandez-Kelly. 2008. "No Margin for Error: Educational and Occupational Achievement among Disadvantaged Children of Immigrants." Annals of the American Academy of Political and Social Science 620:12-36.

Portes, Alejandro, Patricia Fernandez-Kelly, and John H. Hall. 2005. "Segmented Assimilation on the Ground: The New Second Generation in Early Adulthood." Ethnic and Racial Studies 28:1000-1040.

Portes, Alejandro, William J. Haller, and Luis Eduardo Guarnizo. 2002. "Transnational Entrepreneurs: An Alternative Form of Immigrant Economic Adaption." American Sociological Review 67:278-98.

Portes, Alejandro, and Ruben G. Rumbaut. 2001. Legacies: The Story of the Immigrant Second Generation. Berkeley: University of California Press.

2006. Immigrant America: A Portrait. 3rd ed. Berkeley: University of California Press.

Portes, Alejandro, and Min Zhou. 1993. "The New Second Generation: Segmented Assimilation and Its Variants." Annals of the American Academy of Political and Social Science 530:74-96.

Shapiro, Thomas M. 2004. The Hidden Cost of Being African American: How Wealth Perpetuates Inequality. New York: Oxford University Press.

Shapiro, Thomas M., Tatjana Meschede, and Sam Osoro. 2013. “The Roots of the Widening Racial Wealth Gap: Explaining the Black-White Economic Divide," edited by Institute on Assets and Social Policy.

Smith, James P. 2003. "Assimilation across the Latino Generations." American Economic Review 93:315-19.

Smith, Robert Courtney. 2005. Mexican New York: Transnational Lives of New Immigrants. Berkeley: University of California Press.

Soehl, Thomas, and Roger Waldinger. 2012. "Inheriting the Homeland? Intergenerational Transmission of Cross-Border Ties in Migrant Families." American Journal of Sociology 118:778-813.

Solon, G. 1992. "Intergenerational Income Mobility in the United States." American Economic Review 82:393-408.

Spilerman, Seymour. 2000. "Wealth and Stratification Processes." Annual Review of Sociology26:497-524.

Spilerman, Seymour, and Francois-Charles Wolff. 2012. "Parental Wealth and Resource Transfers: How They Matter in France for Home Ownership and Living Standards." Social Science Research 41:207-23. 
Taylor, Paul, Rakeesh Kochhar, Richard Fry, Gabriel Velasco, and Seth Motel. 2011a. Wealth Gaps Rise to Record Highs Between Whites, Blacks, and Hispanics. Washington, DC: Pew Research Center.

Taylor, Paul, Mark Hugo Lopez, Jeffrey S. Passel, and Seth Motel. 2011b. “Unauthorized Immigrants: Length of Residency, Patterns of Parenthood." Washington, DC: Pew Hispanic Center.

Telles, Edward E., and Vilma Ortiz. 2008. Generations of Exclusion: Mexican Americans, Assimilation, and Race. New York: Russell Sage Foundation.

Tienda, Marta. 2010. "Stymied Mobility of Temporary Lull? The Puzzle of Lagging Hispanic College Degree Attainment." Social Forces 88:1807-1832.

US Census. 2012. "Bachelor's Degree Attainment Tops 30 Percent for the First Time, Census Bureau Reports." http://www.census.gov/newsroom/releases/archives/education/cb12-33.html.

Warren, John Robert, and Robert Hauser. 1997. "Social Stratification across Three Generations: New Evidence from the Wisconsin Longitudinal Study." American Sociological Review 62:561-72.

Waters, Mary C., and Tomás Jiménez. 2005. "Assesing Immigrant Assimilation: New Empirical and Theoretical Challenges." Annual Review of Sociology 31:105-25.

Waters, Mary C., Van C. Tran, Philip Kasinitz, and John H. Mollenkopf. 2010. "Segmented Assimilation Revisited: Types of Acculturation and Socioeconomic Mobility in Young Adulthood." Ethnic and Racial Studies 33:1168-1193.

Wolff, Edward N., and Ajit Zacharias. 2009. "Household Wealth and the Measurement of Economic WellBeing in the United States." Journal of Economic Inequality 7:83-115.

Yang, Pa Nhia, and Catherine Solheim. 2007. "Financial Management in Hmong Immigrant Families: Change and Adaptation." Hmong Studies Journal 8:1-33.

Zagorsky, Jay L. 2005. "Marriage and Divorce's Impact on Wealth." Journal of Sociology 41:406-24.

Zhou, Min. 1997. "Growing Up American: The Challenge Confronting Immigrant Children and Children of Immigrants." Annual Review of Sociology 23:63-95.

Zhou, Min, Jennifer Lee, Jody Agius Vallejo, Rosaura Tafoya-Estrada, and Yang Sao Xiong. 2008. “Success Attained, Deterred, and Denied: Divergent Pathways to Social Mobility in Los Angeles' New Second Generation." Annals of the American Academy of Political and Social Science 620:37-61. 